brazilianpoliticalsciencereview

\title{
ARTICLE
}

\section{The Solidarity Economy in South and North America:}

\section{Converging Experiences*}

\author{
Luiz Inácio Gaiger \\ Universidade do Vale do Rio dos Sinos, Brazil
}

This article explores elements that characterize and boost the Solidarity Economy, based on a comparative analysis of experiences in Latin America and North America. The diversity of models and purposes are underlined so as to demonstrate the main approaches and concepts regarding the so-called new expressions of alternative economies. In the South, these initiatives integrate economic and social dimensions, due to their socio-cultural foundations, and also to their specific rationality, in which efficiency and welfare, productivity and participation are inextricably linked. In the United States, an innovative example from the North, new social dynamics are currently developing in a convergent way, such as worker's cooperatives often associated with the solidarity economy movement itself, as well as different overlapping causes and social movements, from immigration to labor rights. The solidarity economy overall adopts another logic, in which the economic, social and political dimensions are integrated, and responds to emancipatory aspirations aiming at promoting global changes. In different contexts, Solidarity Economy organizations play an important role in the development of grassroots initiatives, whose main goals are an equitable and sustainable development as well as effective political citizenship.

Keywords: Solidarity economy; cooperatives; Brazil; South America; United States. 
I

$\mathrm{n}$ the past few years, the solidarity economy has attracted considerable interest both in the North and the South. Since the early 1990s, scholars and activists have highlighted new surges in these initiatives, stressing their element of reciprocity and their tendency of expanding democracy through public spheres, thus involving civil society and generating greater social commitment. These facts have been taken into account in current debates on the major issues facing society, on a national and worldwide scale, thus creating opportunities for collaborative research projects and publications (DEFOURNY and NYSSENS, 2016).

In the North, the solidarity economy has its main antecedents in the historical experience of the social economy, from which it inherited some of its important characteristics, giving rise at times to hybrid designations, like 'social and solidary' economy, or 'new' social economy. The social economy has its roots primarily in France, Belgium and Spain; from these locations, it spread to places outside of Europe, particularly to Quebec, Canada. The concept comprises a set of collective initiatives seeking to establish autonomous and democratic forms of management, which historically have brought about three main subsectors, namely the cooperative, the associative and the mutualist (DEFOURNY, 2005). In these initiatives, the ways in which power is shared and income distributed result from the primacy of people over capital and from the objective being pursued-i.e. providing goods or services to communities and their members. Economic activity and its surplus are a means rather than an end in and of itself. Therefore, they are not primarily concerned with making profit, although they might generate economic profits or surpluses despite being not-for-profit organizations. In respect to this historical legacy, the solidarity economy stands out and is valued for emphasizing democracy and collective participation in local public spheres, as well as for addressing critically the predominant, present-day economic model on the global scale. Alongside similar movements in the South, it aligns itself with the purposes of "another globalization" (LAVILLE, 2004; POIRIER, 2008).

In the South, particularly in Latin America, 'solidarity economy' is the concept most commonly used to refer to collective economic organizations aiming to achieve financial gains and to generate income for their members, as well as benefits concerning quality of life and citizen participation. These initiatives integrate economic and social dimensions, due to their sociocultural foundations and to their rationality, which inextricably links productivity and participation, efficiency and welfare. Because of their 
social embeddedness, sometimes these initiatives also fulfill functions in the fields of health, education and environmental protection, among other areas. Significant efforts are crucial in achieving such purposes, mainly a strong membership commitment to democratic principles and work cooperation (LIANZA and HENRIQUES, 2012).

As a global movement, the solidarity economy in Latin America offers a critical discourse about the capitalist economic system. As we will see, new initiatives flourishing in North America, in particular in the U.S., share the same social landscape. It is therefore quite interesting to compare these historical contexts, in order to identify not only their singular traits, but also their convergences. This is the general aim of the article. It will try to highlight some elements of comparison between the Latin American experience and the North American one, with a particular focus on the U.S., a country in which many new locally-rooted initiatives, innovative ideas and proposals are currently developing, even though they remain unbeknown to most people not directly involved. The article does not attempt to cover the whole landscape of the solidarity economy in Latin America and in the U.S., which is very diverse and has given rise to many different conceptual and theoretical approaches. Instead, it will focus on some relevant topics in order to do a cross-cutting analysis and an assessment of the building-process of alternatives at the local, regional, and global levels.

We will start by briefly taking into account some historical aspects, in order to elucidate the differences between social economy and solidarity economy, and also to explain why today there is more than one conceptual approach with regard to this field of practices. The final pages of this section will be devoted to the relationship between the solidarity economy and the third sector, since this concept is employed in South America and widely used in North America, reflecting a long tradition in the second case, both in social and academic terms. Next, the article will discuss the solidarity economy in Latin America and attempt to further clarify how we can view the solidarity economy on that continent, by comparing it with some similar realities that are sometimes confused or merged with it, such as the popular economy and the informal economy. The emergence of new initiatives in the U.S., equally identified with the solidarity economy and aligned to the purpose of building new forms of economy and society, will be the focus of attention in the following pages. The last section will be devoted to some general remarks concerning the significance of these new expressions of the alternative economy, in particular with respect to their relational and socioeconomic rationality and 
to their intrinsic political dimension. The article concludes with a brief review of the trajectories of the solidarity economy in the South and in the North, highlighting the reasons for its current convergences and the value of its unity in the face of our present and future challenges.

Despite many nuances and variations, as we will see, the South and the North are increasingly coming to a mutual understanding of the solidarity economy and are collaborating to align their goals and actions around alter-globalist causes. Solidarity economic practices, currently valued in the North and in the South, cross countries and continents. Our main argument is that, globally, the solidarity economy adopts another, different logic and nowadays responds to emancipatory aspirations. In different contexts, solidarity organizations play an important role in the development of grassroots initiatives, supporting them as agents of an equitable and sustainable development and towards an effective political citizenship.

\section{Contexts and conceptual perspectives}

The fundamental principles of modern economic solidarity have circulated since the inception of industrial capitalism in the nineteenth century, when they gave shape to the associative, mutualist and cooperative currents of the social economy, as an institutionalized sector in many countries of the North, and some of the South. From social turmoil among populations facing increasing economic exploitation, social disintegration and impoverishment, arose solidarity. As the main purpose of these various currents was to ensure that all members benefitted fairly from the collective economic activity, they adopted autonomous and participatory management forms from the very beginning. Alongside these common roots and convergences, the expressions social (and/or solidarity) economy in the North, as well as solidarity economy in Latin America, correspond to phenomena linked to specific contexts and periods, which explains the multiplicity of approaches and the several designations adopted by social actors and scholars, often related to theoretical frameworks (CORAGGIO, 2007) and institutional traditions.

In the North, the social economy lost strength in the first decades of the 20th century, because of the growing hegemony of the market economy and as a result of its institutionalization as an auxiliary arm of the state (FRANÇA FILHO, 2002). Before that, the social economy opposed the trends of reducing the economy to the market principle 
and to the rationality of capital accumulation. It that way, it played a considerable role in the construction of the welfare state. From the 1970s, the crisis of Keynesian regulation and the resulting social imbalances gave rise to a series of new social experiments that reinvigorated associative and solidarity-based economic practices (LAVILLE, 2004; GARDIN, 2006). Mainly in Europe and in Quebec, the social economy resumed its critical and participatory impulse. Quebec's social economy counts as one of the longest and more continuous stories in this regard, having played a central role in the development of Eastern Canada since the 19th century. Its last configuration "took shape in the 1990s with the convergence between the social and solidarity economy and the state, in the context of a partnership regarding economic as well as social development" (BOUCHARD et al., 2015, p. 06), particularly in order to generate alternatives to the economic crisis and the crisis of the welfare state. Thanks to the effervescent context of that decade, a renewed concept of the social economy was officially recognized and a legal framework has been approved, allowing specific public policies to be addressed in dialogue with the social actors.

Since the 1980s, similar experiences have emerged in the South. A wide range of new or reshaped organizations expanded, such as associations, informal groups, cooperatives, self-managed companies, local initiatives in the field of social services and assistance to the needy, social economy enterprises and solidarity-based financing. Most of them have been driven by social categories relegated to the margins of the conventional systems of employment or income generation, or frustrated in their personal aspirations. Depending on their regional contexts, historical trajectories and schools of thought, these initiatives have been linked to autochthone inheritances and to communitarian economies, or have been put side by side with the popular economy, as in the cases of Bolivia and Ecuador, respectively (VEGA, 2017). Moreover, they have also been considered as the economy's social sector, as in Mexico, which has a supportive national legislation in this regard.

Returning to the overall context, and given the new dynamics and tendencies of the last decades, for much of Europe and South America it has been justified to speak, in general terms, of a new social economy, sometimes called social and solidarity economy, or simply solidarity economy. In South America, the use of the term social economy would be inconsistent if applied regardless of whether an institutionalized corresponding sector exists (as in Argentina and Colombia, to some extent) or not. In 
general, it simply designates earlier forms of the solidarity economy, resulting a few years ago in a preference for the term social and solidarity economy in some countries. Nowadays, the more common concept in South America is that of solidarity economy, which encompasses economic initiatives aimed not only at generating employment and income for their members but also at enhancing their quality of life more broadly, for example through social benefits or public recognition allowing greater citizen participation. Solidarity involves cooperation in the productive realm and in the socialization of the means of production, thereby dissolving the separation between capital and labor typical of wage employment. For that reason, many authors on the South American continent see the solidarity economy as a field not only distinct, but also separate from the capitalist economy or as a future alternative to capitalism (SINGER, 2002).

In France and Quebec, the adoption sometimes of the combined expression social and solidarity economy should be seen in relation with a critical aspect regarding the way in which the social economy is commonly perceived, that is, as being similar to the prevailing definition of the third sector, or of non-profit organizations. Given this, the corresponding economic activities-concerning mainly charity work, volunteering and social assistance- are not considered as the real economy, which would be the realm of the private sector instead. As a consequence, the social economy remains a secondary or residual part of the economic landscape. Against that, the solidarity economy advocates a more transformative approach to economic activism. An emphasis is put on the solidarity element, in order to stress the crucial role of the principles and values supposed to drive the current renewal of alternatives, not only in a specific sector, but in the entire economy and society, with a view to long-term global transformation.

In the U.S., as we shall see in greater detail later on, new social dynamics have been developing recently, such as worker cooperatives often associated with larger movements, including the solidarity economy movement itself, as well as various overlapping causes, from labor rights to immigration rights (KAWANO et al., 2010). However, until 2005-2007 there was no "overarching framework that could bring together alternative practices that found a place under rubrics such as cooperative, nonprofit organizations (NPOs), community economic development, local development, etc" (POIRIER, 2008, p. 10). The expression social and solidarity economy gained acceptance and use among activists in the U.S., under the influence of international networks and 
meetings, especially the Intercontinental Network for the Promotion of the Social Solidarity Economy (RIPESS) and the World Social Forum, during the 2000s' worldwide struggles against neoliberal globalization.

Another point should be stressed before addressing the solidarity economy in Latin America and in the U.S.: the way in which the third sector is commonly understood in Latin America, and sometimes also in Europe, and how it relates to the notion of solidarity economy. Indeed, the use of the third sector concept in some non-Anglo-Saxon countries differs, in the main, from the usual meaning of the term in the United Kingdom and the United States. This has already been carefully analysed, 'inter alia', in a book edited by EVERS and LAVILLE (2004, p. 04) in respect to the European tradition: "the European third sector cannot be equated either with the narrow concept of voluntary sector or with the U.S. notion of non-profit sector". Indeed, in most English-speaking countries the third sector is basically related to the notion of 'non-profit' sector, used to describe what, in the private sector, is economic at the same time as it is social, giving primacy to its social dimension. Against that, one should highlight from the outset that the original focus of the third sector proposed by the prominent Anglo-Saxon approach connects that concept to the non-profit sector and to voluntary work, as opposed to the economic sector, where profit, trading and utilitarian relations would be the rule. However, identifying profit with an anti-social economy-in other words, in strict relation to capitalist premises and private accumulation-ultimately amounts to accepting the reduction of the entire economic sphere to its market sector and to the extraction of labor surplus by capital. Only such a misleading perspective hinders recognition of the truism that there is, in fact, no contradiction in mutual-aid initiatives of the social and solidarity economy that earn and distribute some of their profits to members.

That is why in those cases the third sector is usually considered as something similar to non-profit organizations (NPOs), and sometimes it is seen only as charities through which philanthropic and assistance entities come to aid the poor without questioning the existing social structures. In contrast, social and solidarity economy organizations seek to generate work and provide services, producing surplus collectively to that end. Since these concepts refer to organizations aiming at financial gains and welfare for their members, the social and solidarity economy on one side, and the third sector on the other, correspond to non-overlapping sets of organizations. 
Furthermore, the growth of the third sector or volunteering does not mean an increase in social solidarity, but may reflect or imply reversals in the recognition of social rights and in the guarantees of the state geared towards their fulfillment.

Despite this, third sector organizations may support grassroots initiatives and the latter may generate new organizations morphologically classifiable as part of the third sector. There are linkages between one and the other.

On the one hand, it could be claimed that there are similarities between the structures and logics of the social and solidarity economy and those of third sector organizations. Both of them exhibit institutional autonomy and proficiency in creating networks, while avoiding hierarchical structures. Their action is decentralized, forming a plural field in which greater affinities generate new identities, in a continuous process of fusion and recomposition. Moreover, solidarity-based enterprises tend to create or consolidate countless intermediary and representation entities, such as associative unions, exchange networks and support organizations. Hence, third sector initiatives can benefit from the existence of these instances and from the result of their work; in this sense, it is possible to say that the social and solidarity economy expands and empowers third sector organizations. From these viewpoints, they have systemic similarities and communication channels that distinguish them from the reality of the so-called first and second sectors (i.e., the market and the state).

However, on the other hand, both the Latin American and the European historical experiences allow us to contrast the social and solidarity economy with the much narrower notion of non-profit sector. In general, the Latin American experience is closer to the European experience than to the North American one in this regard. It is important to highlight a few points. Firstly, in Latin America the initiatives and organizations that are outside the first and second sectors cannot be considered the same as the voluntary sector or the non-profit sector. As in Europe, a number of philanthropic private organizations developed on the Latin American continent based on volunteer work. Despite this, as we have seen, social initiatives also include associations and cooperatives supplying services or involved in economic production. Such collective organizations basically count on the paid work of their members and seek profitability in the market, even though profit and accumulation of capital are not their determining guidelines. Particularly prominent in this field are the solidarity 
economy enterprises, which are even more distant from the concepts of voluntary and non-profit sector.

Secondly, in Latin America it also does not make sense to place the solidarity economy in conceptual opposition to the state and the market. It would be better to acknowledge the solidarity economy as another way of producing and circulating goods and services, and thus of ensuring the material survival of a large number of people; it is not a sector that would function devoid of any relationship with the market or with the economy itself. The challenge, once again, consists in going beyond a limited approach of the economy, which restricts it to the utilitarian logic of the capitalist market. Exactly the same understanding is shared by practitioners and scholars in respect to the solidarity economy in the U.S., which we will address later.

Instead of seeing itself as a subsector of social economy, or even of the third sector, this vision sees solidarity economy as an approach that has the potential to change all the economy. Said otherwise, instead of seeing itself as just a sector doing economic activities with values and principles of solidarity which are different, this vision also shows the way for transformation of the economy as a whole. This approach also allows, and even encourages, joining forces with all social movements who want a different economy, driven to satisfy human needs instead of being driven first of all for profits (POIRIER, 2008, p. 21).

Thirdly, the social and solidarity economy also needs the state, because it provides decisive leverage to establish and consolidate multiple economic sectors. Furthermore, the feasibility of solidarity businesses requires other regulating principles in the economy. It should also be added that the democratic principle is essential for the social and solidarity economy, which is not true of all third sector organizations-many of which are not concerned about the structural dimension of inequalities and, therefore, of social change.

This leads us to agree with Evers and Laville (2004): "the line of demarcation is not to be drawn between for-profit and non-profit organizations but between capitalist organizations and social economic organizations, the latter focusing on generating collective wealth rather than a return on individual investment" (EVERS and LAVILLE, 2004, p. 13). Following Defourny (2005), one can say that the European approach, as well as the Latin American and the more recent one brought about by the solidarity economy in the U.S. seem "to carry more of a North-South perspective, insofar as 
improving living conditions in many countries often requires the distribution of profits among the members of cooperatives and other groups of producers". This perspective also allows us to notice, when analysing conditions of emergence and development, "astonishing convergences (...) between the associative proliferations of the North and, on the other [hand], the rise of civil societies in the South" (DEFOURNY, 2005, pp. 240241).

In this regard, some aspects have been gradually shared across the Atlantic, from East to West, from South to North. One of them is a new understanding of what solidarity may mean today, but also a growing entrepreneurial spirit emerging from civil society thanks to innovative social movements. To understand it better, let's start with the South.

\section{A matter of protection and social change}

In South America, the emergence of the solidarity economy in the 1980s gave continuity and renewed support to a long and rich history of popular solidarity. Throughout the continent, the solidarity economy has remote antecedents, from indigenous pre-Columbian forms to collective systems adopted by freed slaves. The varied landscape of the continent includes realities determined mostly by the precarious conditions of wage workers integrated in the peripheral economy of underdevelopment, and also areas in which communities, especially indigenous peoples, manage to protect their own ways of life and keep the capitalist labor market at bay, even if this alternative usually comes at the price of cultural marginalization and extreme poverty.

These various configurations, amplified by national and regional contrasts, render it difficult to draw one overall portrait of the solidarity economy. They also explain why distinct manifestations coexist in Latin America, spanning the informal collective economy and the cooperative sectors, as well as correlated terms such as popular solidarity economy, community economy, labor economy, socioeconomy and wellbeing (Buen vivir), among others (CATTANI et al., 2009). A common denominator is the unwillingness of the protagonists of these initiatives to live according to the precepts that shape societies' rise from peripheral capitalism - in terms of their intrinsically weak or anti-social character. In other words, in many cases these manifestations express a refusal to abandon social systems in which economic and social relations are intertwined, and in which reciprocity and trust prevail. Essentially, the solidarity 
economy aspires to these ways of living, and engages in either salvaging them or working towards their creation.

To give an example from the South, in Brazil the solidarity economy has been gradually on the rise since the 1980s, with a deep-rooted-although not always continuous-history of solidarity-oriented values. Not-for-profit and self-managed projects are an indelible mark of the solidarity economy in this country. One contributing factor for the increasing number of initiatives observed over recent years is the structural crisis that hit the Brazilian labor market and whose impacts have been reinforced by the withdrawal of the State. Another important reason is the mobilization of social movements, labor unions and citizen entities, unwavering in their commitment to establish and foster mutual help and economic cooperation practices. Both in the countryside and in the suburbs, thousands of small community-based initiatives have been taking root for a long time, adopting solidarity economic practices that have since spread and gained broader recognition.

A particularity of the solidarity economy in Brazil is that it was surveyed in two national mappings, finalized in 2007 and 2013 each. In the second mapping, about 20,000 solidarity enterprises were registered, $55 \%$ of them located in rural areas, 35\% in urban areas, and 10\% in both. As for the legal format adopted, $60 \%$ of them were associations, 09\% were registered as cooperatives and 30\% remained informal, especially small groups in urban peripheries. The main economic activities carried out jointly by the solidarity enterprises were: production of goods (56.2\%), consumption of goods or services, or use of equipment and infrastructure (20\%), trade (13.3\%), labor and service provision (6.6\%), exchange of goods or services (2.2\%), and finance, including savings and credit (1.7\%). The main productive activities were related to agricultural production, food and beverage manufacturing, textile products and recycling, among others (GAIGER et al., 2014, pp. 75-94).

Considering the overall Latin American context, solidarity economy initiatives could be described as having two basic characteristics. Firstly, they are economic alternatives where individuals, who normally make a living out of selling their labor, gather together, and where social groups usually excluded from the conventional state and market wealth generation and distribution process take shelter. Such practices reveal a reappropriation of previous work experiences, which are reconverted along self-management and socialisation principles; or, mostly, they remain anchored in the 
family economy, of which they are an extension and where they find, first and foremost, their essence and functionality. Secondly, the solidarity economy embraces an important portion of the so-called popular economy, a sector driven by the necessity to generate income and fulfil basic needs.

Since the solidarity economy in Latin America encompasses a multitude of social segments, agents and institutions (LIANZA and HENRIQUES, 2012), we should underline that it is not possible to lay down a well-demarcated set of traits; those listed above can be observed in some solidarity initiatives, but certainly not in all of them. Considering this, studies repeatedly agree on the fact that associative enterprises can reach a process of internal growth only under certain circumstances. By adopting a proper economic rationality and planning their investments, these enterprises can mutually reinforce cooperative work and profit. Benefiting from more stability, they not only contribute to the formation of groups and individuals capable of action, but also ensure work and income generation (MIGLIARO, 1990; SINGER, 2002).

That being said, the greatest discrepancy between North and South realities is probably the informality. In Africa and Latin America, informality characterizes the popular economy, which is a major source of the solidarity economy. The history of informality in Latin America is usually considered to span the last five decades, during which populations migrated from rural areas to urban spaces at a rapidly growing rate. More often than not, the formal labor market in the cities proved incapable of absorbing the majority of people seeking work; under such circumstances, there were no means to ensure their integration into the economy. That contingent of society was thus left to its own devices and forced to subsist on temporary labor. This process, in turn, has modified the urban landscape, giving rise to peripheral neighborhoods and expanding the informal economy into a phenomenon of great magnitude.

Over the years, however, the spread and persistence of informality led to the belief that it was in some ways also a choice, intentionally inserted into popular strategies of economic resistance and social mobilization. In countries such as Chile, Peru, Brazil and Uruguay, organized movements that fought for housing, urban services, income and employment emerged in urban peripheries. Community initiatives multiplied and gradually aroused the interest of civil organizations, churches and development institutions, particularly microcredit institutions. Most of these initiatives started their operations through the pioneering women's banks and gave rise to 
grassroots communities, neighborhood associations, unions of family growers and, already in the 1980s, the first collective experiences of income generation that were the precursors of the solidarity economy.

Informality was then reinterpreted as being part of the so-called popular economy, which had its own social logic of promoting community ties and reinforcing solidarism. This new vision offset the poor light in which informality was cast in previous theories. Coraggio (1999), for example, considers that the popular economy has a rationality of its own, guided towards the formation of a collective labor fund through individual and collective strategies that are inseparable from the mesh of social relations in which small-scale economic agents interact. The effectiveness of such strategies, then, is seen to depend on the relative freedom prompted by informality. The material and social assets typical of the informal economy should not be underestimated, but rather valued as means or tools of effective social transformation at the local level.

In 2013, informal groups accounted for $30 \%$ of all enterprises surveyed by the second Brazilian National Mapping of the Solidarity Economy. Several of them have prospered while retaining their informal traits. In these cases, workers dispensed with an attitude of constant adaptation to circumstances in favor of actions that allowed them to take more control of the factors of production and to predict future consequences. In other words, in spite of poverty they recognize themselves as a force capable of creating new situations and influencing local changes. This feeling is particularly favored when workers rely on their social relations. A metamorphosis turns personal ties into a properly enterprising and solidarity economy behavior, sustained by cooperative relationships (MIGLIARO, 1990). Once equipped with this foundation, solidarity enterprises can contribute to overcoming the instability and uncertainty affecting the poor, as far as they attenuate their subordination to the dictates of the prevailing economy and redistribute a portion of the surplus value to the workers. We might say that, from the economic culture viewpoint, such enterprises contribute to the rationalization of solidarity since they stimulate intentional and everyday practices of solidarity (GAIGER, 2006).

We must therefore bear in mind that, even if the popular and informal economy lacks an appropriate institutional framework, it is a relevant part of institutionalized forms of economy insofar as they comply with rules that determine the management of 
informal businesses. Informal, popular and solidarity economy are not equivalent, but compatible terms. In the South, their overlapping compels us to see the logic of informality as an attribute underlying most enterprises of the solidarity economy in the current economic conditions.

\section{New social dynamics in the United States}

Coming forward now to the recent U.S. social landscape leads us to call attention initially to the important role of freely founded associations, driven by active citizens, in the formative process of that country. This associative tradition constitutes the main historical reason behind the American legacy and its worldwide influence, as regards the understanding of the third sector as being equivalent to the non-profit sector. Suffice it to say that, between 1940 and 1980, the number of non-profit organizations in the U.S. rose from about 50,000 to 1.4 million (KRAMER, 2004, p. 219). Thanks in particular to the well-known Johns Hopkins project ${ }^{1}$, for about twenty years the U.S.-led theoretical approach has provided the dominant model for third sector issues, in an increasingly internationalized and multidisciplinary academic research field. Such a theoretical framework focuses mainly or exclusively on the set of non-profit organizationscharities, voluntary organizations and foundations-and excludes cooperatives and various mutual-aid societies. Likewise, that perspective has hitherto remained unaware of many communitarian economic initiatives and small, informal collective enterprises, where people organize the production of key services and goods themselves for their own purposes, and can thus distribute some of their profits to members.

However, the U.S. non-profit perspective is undergoing changes. Indeed, our market economies are made of a much broader organizational diversity than the sole for-profit business model (DEFOURNY and NYSSENS, 2012; 2011). In the context of such diversity, new socioeconomic initiatives have received growing attention from practitioners, academics and governments, who view them as a possible answer to a series of challenges and aspirations of our age; amongst others, the transformation of social protection and solidarity systems, the need for more ethics and transparency in the economic system, the desire for autonomy, meaning and motivation in the

1 The 'Johns Hopkins Comparative Nonprofit Sector Project' was carried out in 43 countries, representing six continents, and has remained a global reference for comparative research both at the national and international levels (SALAMON, 1996; SALAMON and ANHEIER, 1998). 
workplace, etc. In particular, organizations that adopt an entrepreneurial dynamic to provide goods and services while keeping social aims as their primary focus have given rise to a new concept, which has been spreading in Europe and also in the U.S.: that of social enterprises, increasingly referred to as a promising tool to deal with some of the current economic, social and environmental challenges. One of the broader and most influential definitions, given by the EMES European Research Network (DEFOURNY and NYSSENS, 2012), stresses specific governance models, rather than the profile of social entrepreneurs. From this perspective, democratic control or participatory involvement of stakeholders and citizens reflect a quest for more economic democracy inside the organization, in line with the tradition of cooperatives and, more recently, of the social and solidarity economy.

According to COONEY (2015, p. 04), "social enterprise coalesced as a field throughout the 1990s in the U.S.". The same author warns that "in the U.S., although we have seen the for-profit models for social enterprise grow rapidly, social enterprise initiatives are primarily constructed as 'win-win' endeavors that do not 'per se' aim to create an alternative social economy, but rather mix traditional market mechanisms and incentives with social aims" (COONEY, 2015, p. 05). Such enterprises often refer to a triple bottom line, seeking to maximize their financial, social and environmental impact in a positive manner, but typically still assume traditional business forms, instead of those that explicitly prioritize workers' expanded rights. There are exceptions in regard to this trend, such as the Work Integration Social Enterprises (WISE), which correspond to "a subfield of organizations using market based business enterprises to provide employment training and jobs as an avenue for community economic development" (COONEY, 2015, pp. 05-06).

In the midst of all of this rapid growth in social enterprise activity and innovation in the legal infrastructure exists a broad-based population of WISEs, some of which date back to the earliest chapters of social enterprise in the U.S. Today, the WISE population in the U.S. can be divided into three categories: 01. those emerging out of the sheltered workshop model, primarily working with developmentally disabled and cognitively challenged individuals; 02. the WISEs working with unemployed and disadvantaged workers at the end of the labor queue; and 03. the new clustered worker cooperatives that are emerging in some U.S. cities and are inspired by the large 
industrial federation of coops at Mondragon, in the Basque region of Spain (COONEY, 2015, p. 06).

Owned and controlled by their associated members, worker cooperatives focus on employment and community economic development. Their particular aim is to structure a corporation in which the employees have both a share of the profits generated and voice in the governance of the enterprise. As a consequence, worker cooperatives generally "are built around a premise of democratic control whereby workers, typically with one vote per employee regardless of the number of shares owned, take part in all strategic decisions of the firm" (COONEY, 2015, p. 11) ${ }^{2}$. These traits are very close to the self-managed spirit of the solidarity enterprises in Latin America. The similarities are greater still when we place the North-American worker cooperatives inside the recent buoyancy of cooperatives and, as an unifying and supporting force, the solidarity economy movement in the U.S.

Yes! Magazine, a nonprofit publication, supported by its readers' subscriptions and tax-deductible donations, has highlighted these exciting times for cooperatives.

A growing disillusionment with big banks and corporations is sparking interest in economic alternatives, and new opportunities are opening up: the United Steel workers and other unions are exploring worker-ownership as a means to assure stable, living-wage jobs that cannot be outsourced to low-wage regions; communities seeking alternatives to profit-driven corporate health insurance are forming health care co-ops; hundreds of thousands of people who 'moved their money' from Wall Street banks to local banks and credit unions now have a say in how their money is used; consumers are turning to co-ops like Equal Exchange for ethically produced goods, and Equal Exchange, in turn, supports co-ops made up of farmers and producers in some of the world's poorest regions (VAN GELDER, 2013, p. 01).

Another exciting trend for worker cooperatives in the U.S. is a more territorial approach, aimed at laying the roots for community wealth by linking, through public purchasing agreements, worker-owned businesses to anchor-institutions that have a significant infrastructure investment in the community, and are therefore unlikely to relocate-such as hospitals and universities (CASPER-FUTTERMAN, 2011). Such initiatives, commonly referred to as community wealth building, are particularly

${ }^{2}$ Quoting Ellerman, 1984.

(2017) $11(3) \quad$ - 
common in areas where deindustrialization has led to high unemployment and disinvestment in community institutions. City governments are increasingly promoting local social ventures, bringing together worker cooperatives, impact investors, and Community Development Financial Institutions (CDFI).

In 2014, programs supporting worker cooperative development were announced in New York City, Austin (a City Council resolution to support the development of worker cooperatives), and Madison (KELLY and McKINLEY, 2015). To give an emblematic example, Cleveland, Ohio, piloted the aforementioned integral placebased strategy through the Evergreen Cooperative, an effort led since 2007 by the Democracy Collaborative (University of Maryland) and the Cleveland Community Foundation (CCF), which engaged anchor-institutions from the hospital industry, amongst others, to leverage their buying power in arranging procurement from networked worker cooperatives composed of local residents. According to the 2014 Impact Report ${ }^{3}$ of Democracy Collaborative, since that year Evergreen Cooperative operates independently, with its own board of directors and management team. The community wealth building model gained traction in many communities and cities across the country and abroad, like Baltimore, Chicago, Denver, New York City, Preston (United Kingdom), and Toronto (Canada).

The public discourse on social enterprise and community-based development of key-actors, like Democracy Collaborative, highlights some of the values and proposals that have been historically pointed out by worker cooperatives, such as democracy in the workplace, democratized ownership, grassroots participation for sustainability, and a spirit of mutual help. Meanwhile, the cooperative model as a whole is growing in number and size, including the worker cooperatives.

Worker cooperatives are the least common type of cooperative, but they often have the greatest impact on their members. (...) The U.S. Federation of Worker Cooperatives (USFWC), a national organization established in 2004, estimates that there are 300-400 worker-owned cooperatives and democratic workplaces in the United States currently employing 2,500-3,500 worker-owners (ABELL, 2014, pp. 04-05).

The increased number of new initiatives and the wide confluence between their beliefs and expectations gave rise to several meetings and progressive linkages,

${ }^{3}$ Available at < www.democracycollaborative.org/impact2014>. 
including the solidarity economy movement itself. As Kawano (2010) explains, this movement found its inspiration in the same principles that have been common to virtually all initiatives around the world: mutuality, individual and collective well-being, equity, ecological health, grassroots empowerment, social and economic democracy, ethical consumption, sustainability, diversity, and pluralism. It was born in the first U.S. Social Forum $2007^{4}$, where a series of meetings around the solidarity economy resulted in the decision to launch the Solidarity Economy Network (SEN) 5 .

Two years later, in the first Forum of the Solidarity Economy in the U.S, a very diverse mix of practitioners, social activists and trade unionists, academics, and students from various corners of the U.S. met and helped raise the profile of the solidarity economy in the country (KAWANO, 2010, pp. 52-53). Worker, consumer and producer cooperatives, community-run social centers, community land trusts, community development credit unions, alternative currencies, and fair trade initiatives were some of the initiatives that started making connections with each other, sharing values and acting together. "These elements vary greatly in their explicit commitment to solidarity economy principles, but all of them are potential partners in the project of building an economy centered on people and planet" (POIRIER, 2008, pp. 16-17). Both authors give some examples of imaginal cells of the solidarity economy, still fairly isolated in the late 2000s, although clusters were already progressively forming (KAWANO, 20106; POIRIER, 2008).

Considering specific industries, about 30 percent of farmers' products are marketed through co-ops and there are more than 3,000 farmer-owned cooperatives in the U.S.. Almost 10,000 credit unions provide financial services to approximately 84 million members. Nearly 1,000 rural electric co-ops operate more than half of the nation's electric distribution lines and provide electricity to more than 37 million people. More than 6,400 housing cooperatives exist in the U.S., providing 1.5 million homes. Insurance companies owned by or closely affiliated with co-ops served more than 50 million people. More than 50,000 families in the U.S. use cooperative day care

\footnotetext{
${ }^{4}$ A compilation of papers and reports from the U.S. Social Forum 2007 is available in Allard et al., 2008.

5 This decision was encouraged by the Mexican and Canadian members of the American Solidarity Economy Network (RNAES) and the aforementioned Intercontinental Network for the Promotion of Social Solidarity Economy (RIPESS).

${ }^{6}$ Quotations from this article are based on the original English version, written in 2009.
} 
centers. Two million U.S. households receive telephone service from telephone cooperatives.

Community land trusts started spreading in the 1960s, in order to create and ensure affordable housing, as well as parks and businesses. A trust holds the land while houses and businesses may be privately owned. It is a win-win game: "People with limited income can buy a house at below market rates because they do not have to pay for the land. In exchange, they agree to sell their house at an affordable price" (KAWANO, 2010, p. 58). Moreover, community land trusts usually serve as bases for other place-based solidarity activities, such as resident-led neighborhood revitalization urban projects. This is more likely the case when a Community Development Corporation is at work: their numbers increased from less than 200 corporations in the late 1970 s to 4,600 in 2008, managing billions of dollars in assets such as affordable housing, commercial industrial space and jobs. Likewise, Community Development Financial Institutions (CDFI) emerged in the 1980s "with a mission of promoting community development in disadvantaged areas". As of 2008, there were "550 CDFIs managing more than $\$ 6.5$ billion in assets. Credit unions, which are member-owned cooperatives, number around 10,000, provide services to approximately 84 million members and have assets of over $\$ 600$ billion" (KAWANO, 2010, p. 56).

The commons movement, which seeks to protect common goods against private, predatory exploitation, has grown as a way of thinking about and governing resources that communities hold or produce collectively. "Clean air, water, culture, care work (e.g. child rearing and care of the elderly), and the accumulation of knowledgethese are all part of their common resources. There are attempts by businesses to capture these resources, for example by patenting indigenous medicines, or exploit them freely, for example by dumping harmful emissions in the atmosphere" (POIRIER, 2008, p. 17). This strand is connected with the ecological production, whose initiatives converge with the solidarity economy in many ways. Another important tool, the Community Supported Agriculture (CSA) allows consumers to purchase directly from farmers in their community. They started up in the U.S. around 1980 and twenty years later numbered more than 1,000.

This list, though long, is not exhaustive. For instance, one could add the U. S. Fair Trade sector, having in mind that Ten Thousand Villages, based in Akron, Pennsylvania, started in 1946 and is presumably the oldest Fair Trade organization in the world; at the 
end of 2007, Ten Thousand Villages comprised 180 shops, selling almost exclusively handicraft products sourced from more than 100 producer groups in more than 30 countries (KRIER, 2008, p. 109). It seems fair to acknowledge that the solidarity economy also embraces a large range of economic activities, such as care work, that are invisible simply because the aim pursued is not money. Much of society's care work is not paid work, "despite the fact that it accounts for an estimated $\$ 11$ trillion worth of global economic activity. A solidarity economy not only recognizes non-monetized transactions, but also seeks to support them and the social fabric that they strengthen" (KAWANO, 2010, p. 57). Moreover, as women typically do much of this care work, the solidarity economy seeks to recognize and value their invisible labor.

\section{Concluding remarks: an economy where all can thrive}

A dignified and prosperous life for all is a motto in the U.S. that unifies the solidarity economy practices and expectations. So far, there are not any comprehensive mappings or general statistics that quantify the experiences and allow us to assess their general evolution with certainty. Nonetheless, according to reports of anchorinstitutions and publications of sector entities, such as the Federation of Worker Cooperatives, the Project Equity (San Francisco) or the Grassroots Economic Organizing, the prevailing trends are the expansion and dynamization of initiatives, at least on some fronts.

In addition, a recent survey estimates the number of worker cooperatives at 350 companies, with a median number of employees of 10 people. About $60 \%$ of them were set up after 2000, and 31\% after 2010. Among these later ones, $60 \%$ of worker-owners are people of color, while 68\% of total worker-owners are women (HOOVER and ABELL, 2016, p. 09). These cooperatives materialize an ideological and strategic element, consensual among scholars and practitioners: the democratization of ownership and the cooperation between worker-owners, sustaining "models in which the worker-owned and/or self-managed enterprise becomes the dominant economic unit, replacing the privately owned firm and the publicly traded corporation in capitalism and state owned industry in socialism" (ALPEROVITZ et al., 2015, p. 09). That is why this form of organization is the most commonly mentioned as an appropriate blueprint to achieve and consolidate new local bottom-up dynamics. 
In this way, the solidarity economy in the U.S. converges with the experience in Latin America, in which the socialization of the means of production and selfmanagement were always valued (MIGLIARO, 1990; SINGER, 2002). Considering the cooperation between worker-owners as a basis for a broad process of democratization of the economy and the starting point for new bottom-up dynamics is part of the general spirit of the solidarity economy in Latin America and the U.S. At the same time, these premises establish a new rationality in the functioning of solidarity organizations, in which economic and social aspects are not at odds, but intertwine and reinforce each other. The economy ceases to be an end in itself and converts into an instrument of social development and well-being.

Another trait to be highlighted is the relational perspective prevalent in the U.S., according to which each organization and each sector should be examined and promoted in its relations with the local and regional environment. This favors the integration of convergent initiatives, broadening them, as in the aforementioned Evergreen Cooperative. Besides, it keeps reflection connected to praxis, without giving rise to theoretical and ideological purisms (not uncommon in Latin America) in contradiction with the existing dynamics of reality and with the recognition that we are dealing with open and uncertain social processes (ALPEROVITZ, 2015).

This is the strategy of choice to address problems insolvable in the current dominant economic order, such as the ever-widening wealth gap and persistent poverty in the U.S., and to effectively promote a community-led grassroots solidarity economy. Social actors believe that recognizing the solidarity economy is necessary to achieving resilience, economic justice, and community equity. The task is, however, to build a new ecosystem, as the learned lessons of the Cooperative Economics Alliance of New York City (CEANYC) pointed out: "once groups that operate within the solidarity economy begin to recognize their counterparts, there will be tremendous opportunity to combine efforts across sectors". However, "no solidarity economy has ever grown to substantial scale or strength without an elective umbrella organization, and New York is no exception. CEANYC should engage allies and other stakeholders in creating a strong hub organization dedicated to building the solidarity economy in New York City" (CEANYC, 2014, p. 03).

The solidarity economy in the U.S. is conceived as part, and driver, of a new system (ALPEROVITZ et al., 2015). Like in Europe and Latin America, it is not intended 
to be reduced to an intermediate and functional role, between the market and the state. Nor is it accepted that its objectives should be limited to the renewal of a specific sector (the social sector of the economy), or fulfill only a subsidiary function. The perspective of building a new ecosystem affirms-making use of its own semantics-the same that in the Global South most practitioners have announced as a commitment towards a new society or another economy. In this sense, the political dimension of the solidarity economy is undeniable. Politics is conceived and developed as a field of disputes over values and projects, but also as a concrete terrain of action. From local spaces of mobilization and deliberation, the solidarity economy intervenes in public opinion and catalyzes social energies. Thus, it resonates in political institutions and generates favorable government policies, as has already been evident and registered in several Latin American countries (CORAGGIO, 2012; LIANZA and HENRIQUES, 2012).

As we have seen, worker cooperatives and various sets of innovative economic initiatives in the U.S. correspond to current ones in Latin America and Europe, with growing sectoral and global figures. Shall we apply to the broader context of solidarity economy the following verdict, concerning the U.S.' social enterprises and the WISEs in particular, which are more closely related to worker cooperatives?

The future is difficult to predict, but one thing is clear: the social enterprise sector in the U.S. is poised for continued growth and innovation in the decades to come. As one of the older forms of social enterprise in the U.S., WISEs are building stronger associations with each other to help accelerate field-level development. Together these findings suggest that the WISE subsector of the U.S. social enterprise field is one in which big policy changes and growing social movements related to capitalism are potentially effecting large shifts (COONEY, 2015, p. 17).

Regardless of the possibility of giving a clear answer to this, one thing is clear: concrete alternatives are embedded within the dialectics of the very system they fight against and try to overcome. Therefore, it is important to take into account the various historical manifestations of solidarity, considering their moments of expansion, and also their permanence over time, as one of the constitutive elements of society during these past two centuries. Even in periods of regression, the curve has not dropped to a zero level of mobilization. We might say that the appeal to reciprocity and to social participation reflects the condition of the workers' will, conveying a double emancipatory wish: from work alienated by capital, and from the weak sociability 
offered by utilitarianism-both resulting from the implacable logic of the commodity (GAIGER, 2016). It is the ballast of positive experiences and also the citizens' capacity for idealism that can render the solidarity alternative attractive and feasible. The persistent struggle of people in countless concrete experiences in order to face the enormous challenges created by their preference for self-management, equality and freedom, once again is an example of how another type of spirit has survived and nurtured our civilization.

Over the last decades there have been some key differences between the North and the South. The main one concerns the two great backdrops: to fight against social disintegration and to fight for integration. In the North, it has been overall rather a matter of countering the welfare state crisis, the lack of effective regulation and social protection mechanisms. Hence, a matter of reacting to social exclusion by promoting new initiatives and solidarity involvement; and also of aiming at political participation within a system whose capacity to respond has declined, but which nevertheless remains democratic and legitimate. In Latin America, the main historical challenge has consisted in ensuring the material conditions required for the survival of people, to all those who have never become effectively integrated in the market economy and in the social protection system. Thus, the matter of fighting against poverty and misery, of taking support in the hidden virtues of the popular economy to create short and medium term alternatives. As far as the solidarity economy is concerned, this context explains the importance assigned to the topic of possible alternatives to capitalism, in the sense of building a new ecosystem that will not contain processes that exploit and reproduce inequalities (LIANZA and HENRIQUES, 2012; SINGER, 2002).

However, once we pay attention to what is happening in recent years, once we take into account the new solidarity dynamics in the U.S., there is a need to recognize that these historical particularities and boundaries are undeniably blurred. In any case, at the general level, one of the most important contributions of the solidarity economy is that it enables new personal and collective experiences. Instead of presupposing the existence of a new human being, a new individual, as implied in the most prominent socialist approaches, the solidarity economy offers a realistic route to its progressive constitution. Such a perspective inserts the solidarity economy into the sphere in which new economic alternatives to the capitalist economic system are sought, while avoiding the proleptic temptation to fall back on supposedly safe prognoses. In this crucial aspect, 
there is seemingly a growing unity between the South and the North. Despite the deep crisis in which we all meet, there is room for optimism.

The good news is that the inability of traditional politics and policies to address fundamental challenges has fueled an extraordinary amount of experimentation in communities across the United States and around the world. It has also generated increasing numbers of sophisticated and thoughtful proposals that build from the bottom and begin to suggest new systemic possibilities beyond both corporate capitalism and state socialism (ALPEROVITZ et al., 2015, p. 06).

As a final comment, we might add that innovative protagonists must be free to guide themselves by their experience. Daily pauperization and oppression feed new forms of civil society organizations and their claims only when there is an ongoing process of experience, in which the energy contained in the idealizations and in the trust relationships plays an essential role. More broadly speaking, the attempts at resisting the despotism of capital and at humanizing civilization are occurring in our times in the context of a complex worldwide transition, which is frightening because there seems to be no end in sight; also, there is a lack of social safety nets, as well as of well-defined roles and of an already implemented and tested project for the whole of society. In such a historical situation, following Dubet (1994), experience becomes the key of psychosocial dynamics, driving the actors - that is, individuals that are both capable of taking care of themselves and of acting together - to build new scenarios towards a meaningful life.

Translated by Priscilla Kreitlon Submitted on April 18, 2017 Accepted on July 07, 2017

\section{References}

ABELL, Hilary (2014), Worker cooperatives: pathways to scale. Democracy Collaborative. Available at <http://democracycollaborative.org/content/workercooperatives-pathways-scale>. Accessed on April 11, 2017.

ALLARD, Jenna; DAVIDSON, Carl, and MATTHAEI, Julie (Eds)(2008), Solidarity economy: building alternatives for people and planet. Papers and reports from de 2007 US Social Forum.

ALPEROVITZ, Gar (2015), Inequality's dead end-and the possibility of a new, long-term direction. Nonprofit Quarterly. Vol. 10, March Digital Issue. 
ALPEROVITZ, Gar; SPETH, James Gustave, and GUINAN, Joe (2015), The next system project: new political-economic possibilities for the $21^{\text {st }}$ century. Democracy Collaborative. Available at <http://democracycollaborative.org/content/next-systemproject-new-political-economic-possibilities-twenty-first-century>. Accessed on Accessed on April 11, 2017.

BOUCHARD, Marie J.; CRUZ FILHO, Paulo, and ZERDANI, Tassadit (2015), Social enterprise in Québec: the social economy and the social enterprise concepts. EMES Working Papers, № 23.

CASPER-FUTTERMAN, Evan (2011), Back to (non) basics: worker cooperatives as economic development. Berkeley Planning Journal. Vol. 24, № 01, pp. 115-129.

CATTANI, Antonio David; GAIGER, Luiz Inácio; LAVILLE, Jean-Louis, and HESPANHA, Pedro (Eds), (2009), Dicionário internacional da outra economia. Coimbra: Almedina. 346 pp..

CEANYC (2014), Summary of findings: expanding New York City's solidarity economy. New York. pp. 01-11.

COONEY, Kate (2015), Social enterprise in the United States: WISEs and other workerfocused models. ICSEM Working Papers. № 09.

CORAGGIO, José (1999), Política social y economía del trabajo: alternativas a la política neoliberal para la ciudad. Madrid: Miño y Dávila Editores. 143 pp..

CORAGGIO, José Luis (Ed) (2007), La economía social desde la periferia: contribuciones latinoamericanas. Buenos Aires: Altamira. 416 pp..

CORAGGIO, José Luis (Ed) (2012), Conocimiento y políticas públicas de economía social y solidaria: problemas y propuestas. Quito: Editorial IAEN. 224 pp..

DEFOURNY, Jacques (2005), Économie sociale. In: Dictionnaire de l'autre économie. Edited by LAVILLE, Jean-Louis and CATTANI, Antonio. Paris: Desclée de Brouwer. pp. 233-241.

DEFOURNY, Jacques and NYSSENS, Marthe (2016), Fundamentals for an international typology of social enterprise models. EMES Working Paper, № 33.

DEFOURNY, Jacques and NYSSENS, Marthe (2012), The EMES approach of social enterprise in a comparative perspective. EMES Working Papers, № 12/13.

DEFOURNY, Jacques and NYSSENS, Marthe (2011), Approches européennes et américaines de l'entreprise sociale: une perspective comparative. Revue internationale de l'économie sociale. № 319, pp. 18-35.

DUBET, François (1994), Sociologie de l'expérience. Paris: Seuil. 271 pp..

(2017) $11(3) \quad$ a $\quad$ e0002-25/27


ELLERMAN, David (1984), Workers cooperatives: the question of legal structure. In: Worker cooperatives in America. Edited by JACKALL, Robert and LEVIN, Henry M.. Berkeley/Los Angeles/London: University of California Press. pp. 257-274.

EVERS, Adalbert and LAVILLE, Jean-Louis (Eds) (2004), The third sector in Europe. Cheltenham (UK) / Northampton (USA): Edward Elgar. 266 pp..

FRANÇA FILHO, Genauto Carvalho (2002), Terceiro setor, economia social, economia solidária e economia popular: traçando fronteiras conceituais. Bahia Análise \& Dados. Vol. 12, № 01, pp. 09-19.

GAIGER, Luiz Inácio Germany (2006), A racionalidade dos formatos produtivos autogestionários. Sociedade e Estado. Vol. 21, № 02, pp. 513-544.

GAIGER, Luiz Inácio Germany (2016), A descoberta dos vínculos sociais: os fundamentos da solidariedade. São Leopoldo: Editora Unisinos. 252 pp..

GAIGER, Luiz Inácio Germany and ECOSOL, Grupo (2014), A economia solidária no Brasil: uma análise de dados nacionais. São Leopoldo: Oikos. 160 pp..

GARDIN, Laurent (2006), Les initiatives solidaires: La réciprocité face au marché et à l'état. Ramonville Saint-Agne: Éditions Ères. 190 pp..

HOOVER, Melissa and ABELL, Hilary (2016), The cooperative growth ecosystem. Democracy at Work Institute and Project Equity. Available at <http://www.projectequity.org/about-us/publications/>. Accessed on April 11, 2017.

KAWANO, Emily (2010), Hacia la luz: el movimiento emergente de economía solidaria en Estados Unidos de Norteamérica. Cayapa-Revista Venezolana de Economía Social. Vol. 10, № 19, pp. 50-64.

KAWANO, Emily; MASTERSON, Thomas Neal, and TELLER-ELLSBERG, Jonathan (Eds) (2010), Solidarity economy I: building alternatives for people and planet. Amherst, MA: Center for Popular Economics. 365 pp..

KELLY, Marjorie and McKINLEY, Sarah (2015), Cities building community wealth. Democracy Collaborative Report. Available at $<$ http://democracycollaborative.org/content/cities-building-community-wealth-0>. Accessed on April 11, 2017.

KRAMER, Ralph M. (2004), Alternative paradigms for the mixed economy: will sector matter? In: The third sector in Europe. Edited by EVERS, Adalbert and LAVILLE, JeanLouis. Cheltenham (UK) / Northampton (USA): Edward Elgar. pp. 219-236.

KRIER, Jean-Marie (2008), Fair trade 2007: new facts and figures from an ongoing success story. Culemborg: The Dutch Association of Worldshops. 160 pp..

LAVILLE, Jean-Louis (Ed) (2004), Economía social y solidaria. Una visión europea. Buenos Aires: Altamira. 235 pp.. 
LIANZA, Sidney and HENRIQUES, Flávio Chedid (Eds) (2012), A economia solidária na América Latina: realidades nacionais e políticas públicas. Rio de Janeiro: Pró Reitoria de Extensão UFRJ. 204 pp..

MIGLIARO, Luis Razeto (1990), Las empresas alternativas. Montevideo: Editorial Nordan-Comunidad. 196 pp..

POIRIER, Yvon (2008), Another economy is possible! Visions related to building the solidarity economy and related alternatives in North America. Available at $<$ tttps://ripessna.wordpress.com/resources/solidarity-economy-in-north-america-ahistory/>. Accessed on April 11, 2017.

SALAMON, Lester M. (1996), Defining the nonprofit sector: the United States. Working Papers of the Johns Hopkins Comparative Nonprofit Sector Project. № 18.

SALAMON, Lester M. and ANHEIER, Helmut K. (1998), Social origins of civil society: explaining the nonprofit sector cross-nationally. Journal Voluntas. Vol. 09, № 03, pp. 213-248.

SINGER, Paul (2002), Introdução à economia solidária. São Paulo: Fundação Perseu Abramo. 127 pp..

VEGA, Silvia (2017), La economía solidaria y comunitaria en Ecuador y Bolivia. Interpretaciones a la experiencia de los gobiernos de Rafael Correa y Evo Morales. Doctoral Thesis. Facultad Latinoamericana de Ciencias Sociales. FLACSO Ecuador.

VAN GELDER, Sarah (2013), How cooperatives are driving the new economy. Available at $\quad<$ http://www.yesmagazine.org/issues/how-cooperatives-are-driving-the-neweconomy>. Accessed on April 11, 2017. 